\title{
DECISION DIVERSION IN DIVERSE TEAMS: FINDINGS FROM INSIDE A CORPORATE BOARDROOM
}

\author{
SARAH HARVEY 1 \\ University College London
}

STEVEN C. CURRALL

Southern Methodist University

TOVE HELLAND HAMMER

Cornell University

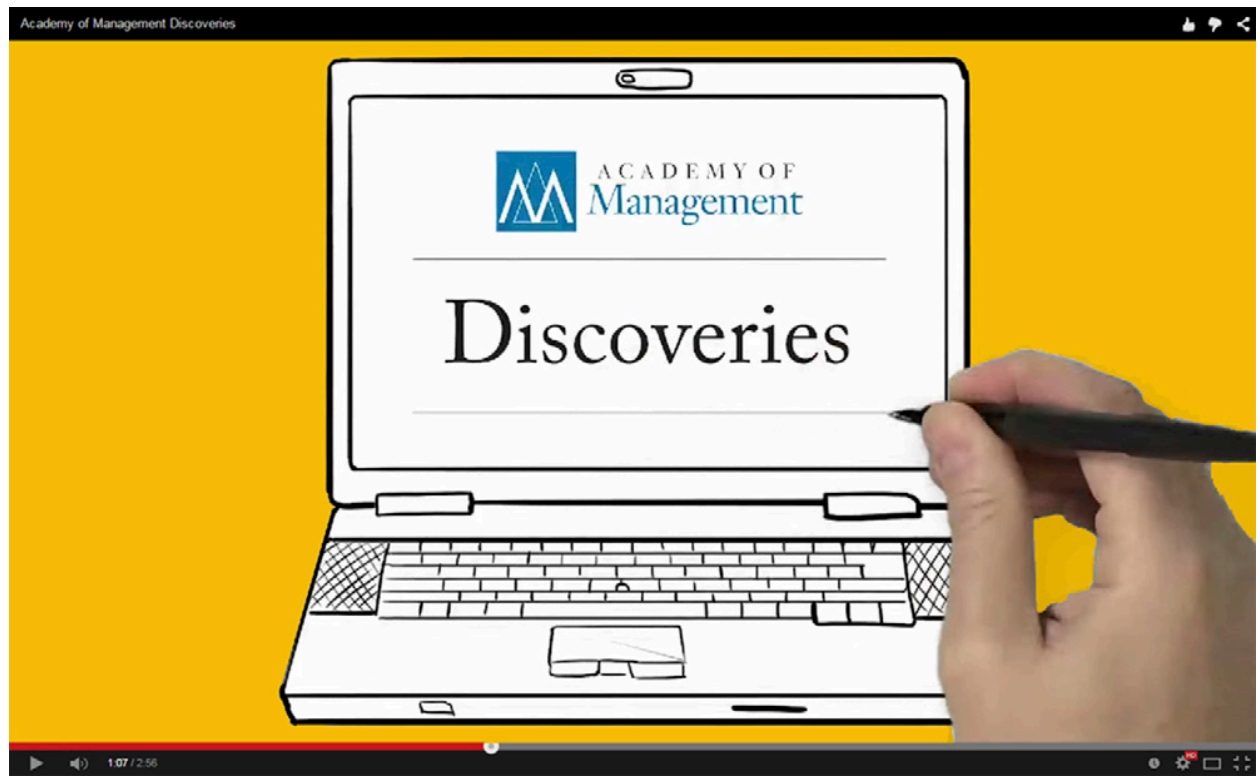

Using qualitative data from a 5-year participant observation study conducted inside the corporate board of a publicly-held company, we discovered what happened when team composition changed to increase the diversity of perspectives and interests represented on the team. Based on board meeting transcripts over the 5-year period, we observed that a change in team composition was followed by a process we label decision diversion, a dysfunctional process in which the team replaced its goal of effective task performance with negotiating the interests of subgroup members. A key insight of our study is that this process unfolded as team members attempted to engage in effective task-based information analysis and decision-making. Our study suggests that the traditional assumptions underlying the understanding of team composition may be insufficient. We provide alternative explanations for the origins of the dynamics of decision diversion in teams.

${ }^{1}$ Corresponding author. 
Editor's Comment

In their search for the microprocesses through which diverse team members interact with one another, Harvey, Currall, and Hammer discover a process they call decision diversion: the team's replacement of its goal of effective task performance with negotiating the interests of subgroup members. This discovery emerges from the in-depth, longitudinal study of the meetings of a corporate board. Quoting one of the referees, "the interesting insight is that increases in the diversity of perspectives and interests represented on the board required processing and integrating large amounts of complex information which the board failed to do, resulting in decision diversion." This finding challenges some established assumptions, and its implications for our understanding of team composition suggest new questions for research on team diversity.

Africa Arino, Action Editor

Composing teams such that members represent diverse perspectives and interests is one mechanism recommended for improving decision-making in boards of directors (Forbes \& Milliken, 1999; Hambrick \& Mason, 1984), top management teams (Bantel \& Jackson, 1989; Simons, Pelled, \& Smith, 1999), new product development teams (Ancona \& Caldwell, 1992; Lovelace, Shapiro, \& Weingart, 2001), sales teams (Jackson \& Joshi, 2004), and a variety of other work teams. To follow research advice to diversify teams to improve decision-making and performance, managers may need to alter team composition. To date, however, research has primarily treated diversity as a fixed input to team decision-making and overlooked the microprocesses that occur after a change in composition (Choi \& Thompson, 2005; Levine, Choi, \& Moreland, 2003; Lewis, Belliveau, Herndon, \& Keller, 2007; Srikanth, Harvey, \& Peterson, 2016; van der Vegt, Bunderson, \& Kuipers, 2010).

That oversight is both theoretically and practically important. Theoretically, it is important to examine the team dynamics that occur after a change in composition because empirical findings on the benefits of diversity have been inconsistent (van Knippenberg \& Schippers, 2007). Diverse teams often fail to reach their potential (Mannix \& Neale, 2005). Literature has portrayed poor performance in diverse teams as resulting from conflict between team members and a lack of task-focused communication that develop quickly after team formation (van Knippenberg \& Schippers, 2007; Williams \& O'Reilly, 1998). Teams are only expected to reap the informational benefits of diversity if they can overcome those interpersonal challenges. However, research tends to examine more generalized constructs after teams have interacted for some time (Srikanth et al., 2016). It is possible that the microprocesses that produce effects in the longer term are not always those that are hypothesized in the

Author's voice:

How and why did you get involved in this project? literature. Specifically, some research suggests that processing a diversity of information may create short-term cognitive challenges that limit team effectiveness in the longer term (e.g., Cronin \& Weingart, 2007; Dahlin, Weingart, \& Hinds, 2005). Research into the microprocesses that follow a change in team composition is necessary to understand how the effects of diversity unfold over time.

Practically, in the pursuit of task performance, managers must often add new members to a team to deal with an increased workload, to access taskrelevant skills and resources, or to adjust to changing task demands, or remove or replace poorly performing members (Daily \& Dalton, 1992; Hambrick \& D’Aveni, 1992; van der Vegt et al., 2010). Research suggests that team turnover typically disrupts team performance (Levine et al., 2003), challenging managers' ability to use that intervention fruitfully. Moreover, when teams change composition, they are likely to draw on new members from a different social entity (e.g., a different team, functional specialty, or organization) who represent a particular knowledge base or interest group. Those new members often provide an opportunity for subgroups to form that can exacerbate the effects of diversity (Carton \& Cummings, 2012; Li \& Hambrick, 2005).

Our study of a decision-making team-a corporate board of directors-over a 5-year period directly examined the dynamics that followed three changes in team composition. A corporate board is an appealing context for examining how changes in composition affect processes in diverse teams. Research on corporate boards recognizes that in some ways, boards function like other small groups (e.g. Tuggle, Schnatterly, \& Johnson, 2010). Two features of boards, however, enable that context to provide new insights into the dynamics of changing team composition. One feature is that board composition often changes to improve performance if a firm is facing serious financial challenges (Hambrick \& D'Aveni, 1988), as did the board in our study. A second feature is that board members may be chosen to represent different sub groups (Eisenhardt, 1989a), creating a complex subgroup structure in which coalitions representing 
diverse interests must negotiate outcomes (Cyert \& March, 1963). These features mean that boards repeatedly struggle with a heterogeneity of viewpoints, bringing team dynamics to the surface in ways that examining teams in laboratory and other small group settings may not (Glaser \& Strauss, 1967).

Despite changing the composition of the board in the ways prescribed by the literature, the firm we studied went bankrupt after 5 years. We further observed, however, that the board's decision-making difficulty could not easily be attributed to the dysfunctional dynamics that the literature has historically used to characterize diverse groups. Instead, we discovered an alternate process that we label decision diversion. Decision diversion is a pattern of team interaction in which changes in team composition set into action informational and status dynamics that gradually shifted the team's goals away from taskbased information analysis focused on advancing the survival of the firm and toward negotiating the interests of subgroup members. At the heart of that shift was the obstacle that changes in composition created to the board, who then faced the challenge of assimilating and integrating a wide diversity of opinions and information. When the board was unable to effectively process an increasingly wide variety of perspectives and information, their attention became diverted to solving problems that were more tractable, but often less important.

The process of decision diversion shares commonalities with concepts investigated in previous research, such as information overload (Miller, 1956; O’Reilly, 1980), satisficing (Cyert \& March, 1963; Simon, 1957), goal displacement (Kerr, 1975; Merton, 1957), conflict, and coalition formation (March, 1962). What was surprising was not that any of those concepts occurred in the board we studied, but rather a) that they occurred in response to changes in team composition that were aimed at improving decisionmaking and b) the precise processes through which they were ordered. Specifically, during the process of decision diversion, dysfunctional social processes emerged over time because of the failure of decisionmaking. Complexity of information and decisions in the context of financial crisis were the primary source of the team's difficulty. Ironically, attempting to understand and satisfy various subgroups enabled subgroup-based negotiating to take place and interfere with effective decision-making.

To further explain the process through which changing team composition was associated with decision diversion in the board of directors in our study, we present qualitative process analyses of team interactions that occurred inside the boardroom. We examined how changes in composition affected boardroom discussions by studying the board interactions leading up to board decisions. Specifically, we compared boardroom interactions and associated decisions that occurred following a change in composition with boardroom interactions that occurred after a period of interaction when board composition was relatively stable.

\section{CHANGING TEAM COMPOSITION}

A foundational idea for understanding team diversity and team turnover is that changing team composition may interfere with interpersonal interactions between team members, but can aid team decision-making by improving the team's informational processes (Mannix \& Neale, 2005; Milliken \& Martins, 1996; Srikanth et al., 2016; van Knippenberg \& Schippers, 2007). Examining research on team diversity, subgroups, and team turnover reveals three implications of this model for understanding how a change in team composition may influence team dynamics and decision-making. Some evidence, however, also reveals that each expectation may be oversimplified.

The first implication is that interpersonal and subgroup dynamics are at the root of the difficulty that faces diverse teams. Diversity can inhibit the development of effective interpersonal relationships between team members (Williams \& O’Reilly, 1998). Individuals tend to identify with similar others and to communicate less with, have less trust in, and have more conflict with those who are dissimilar to themselves (Hogg \& Terry, 2000; Tajfel \& Turner, 1979). Distinct, internally homogeneous subgroups can emerge when team members differ from one another on multiple demographic characteristics (Lau \& Murnighan, 1998), when team members act as representatives of different social entities such as job functions or departments (Li \& Hambrick, 2005), or when team members have different bases of knowledge and information (Carton \& Cummings, 2012). Dysfunctional interpersonal processes are expected to emerge relatively early after group formation and to subsequently disrupt a team's information processing (van Knippenberg, De Dreu, \& Homan, 2004). Thus, when new members are brought onto the team precisely because they represent a different set of skills, interests, or information than those currently on the team, subgroups may form, providing the team with a broader base of knowledge for decision-making (Bezrukova, Jehn, Zanutto, \& Thatcher, 2009).

\section{Author's voice:}

What was the most difficult or challenging aspect of this research project and paper? 
However, emerging research challenges this view. It suggests that differences in social categories between team members can improve team decision making by signaling to team members to expect differences in information and interests, helping them to uncover and use members' unique information in the short term (Loyd, Wang, Phillips, \& Lount, 2013; Phillips, Mannix, Neale, \& Gruenfeld, 2004; Rink \& Ellemers, 2006).

The second implication is that access to a diverse range of perspectives and information is the key benefit of diversity. Research on team composition suggests that diverse groups, particularly those with deep level differences in knowledge and perspectives, engage in more rigorous and thorough discussion and debate (Milliken \& Martins, 1996). Exposure to a new perspective improves creativity and decisionmaking (Loyd et al., 2013; Nemeth, 1986), which can lead to increased task conflict (Simons et al., 1999) and information elaboration (van Knippenberg et al., 2004) in diverse teams. New team members have the potential to bring new knowledge, ideas, or interests to the team (Choi \& Thompson, 2005). The presence of moderate faultlines between subgroups has been found to improve team performance by surfacing differences between team members (Gibson \& Vermeulen, 2003; Thatcher, Jehn, \& Zanutto, 2003). At the same time, diversity in information can be difficult for teams to coordinate in the short term (Cronin \& Weingart, 2007; Dahlin et al., 2005), challenging the notion that access to more diverse information will necessarily improve decision-making. For example, access to a broad range of information can lead to information overload (O’Reilly, 1980) and be difficult for teams to effectively integrate and synthesize (Harvey, 2013).

The third implication is that teams can overcome the challenge of diversity when they attempt to uncover, understand, and integrate one another's perspectives (Ely \& Thomas, 2001). One approach to overcoming the challenges posed by diversity taken in previous research has been to identify moderators, such as team identification, team culture, and cooperative norms that enable teams to build stronger interpersonal relationships (Chatman \& Flynn, 2001; Earley \& Mosakowski, 2000; van der Vegt \& Bunderson, 2005; see Mannix \& Neale, 2005 for a review). The negative effects of subgroups can be reduced by strengthening the interpersonal relationships between members of the subgroups (Bezrukova et al., 2009). However, those processes may also dampen the benefit of informational diversity. When newcomers join a group they are likely to feel pressure to integrate into the team by building positive interpersonal relations with other team members (Rink \& Ellemers, 2009). The desire for positive interpersonal relations may cause new members' opinions and ideas to converge with those of the team (Levine et al., 2003). Alternatively, rather than integration, attempting to value all team members' perspectives may lead to compromise or satisficing.

In sum, there may be reason to question the model that changing team composition may interfere with interpersonal interactions between team members, but can aid team decision-making by improving the team's informational processes. Little research, however, has empirically examined the mircoprocesses through which diverse team members interact with one another. It is therefore unclear how changing the composition of a team will influence interactions between team members upon the team's recomposition.

In the present research, we ask how changing team composition affects team dynamics and decision-making processes. To address that question, we examine team interactions after changes in team composition using data from a 5-year study of a board of directors as the empirical setting. We draw on qualitative methods, which "are especially useful for surfacing new phenomena" (Ariño, Le Baron, \& Milliken, 2016), and therefore appropriate for analyzing previously unexamined microprocesses in diverse teams.

\section{THE TEAM IN OUR STUDY: THE BOARD OF DIRECTORS}

Our study of how changing team composition affects team dynamics and decision-making is based on participant observer data collected from the board of directors of a large nationally known U.S. meatpacking company. Table 1 highlights key features of the board. During the period of our study, the firm had annual sales of approximately $\$ 425$ million and employed 3,000 employees at its headquarter facility in a Midwestern state and in smaller facilities throughout the Midwest and Southwest. At the beginning of our study, the firm was experiencing significant financial distress from declining competitiveness relative to other meatpackers.

The board of directors is an ideal context for investigating our research question for two reasons. First, boards are often reconstituted to improve firm performance, for example, outside directors are often brought onto boards to represent a broad array of perspectives and interests and to increase the independence of the board (Eisenhardt, 1989a) and board

\section{Author's voice:}

How did you get access to the research site and data? 
TABLE 1

Characteristics of Firm and Board of Directors

\begin{tabular}{|c|c|}
\hline Characteristic & Firm/Board \\
\hline $\begin{array}{r}\text { Board size and } \\
\text { composition }\end{array}$ & $\begin{array}{l}\text { Six inside directors; } 10 \text { outside directors. } \\
\text { Chairman separate from CEO. }\end{array}$ \\
\hline Standing committees & $\begin{array}{l}\text { Audit committee. } \\
\text { Employee relations committee. } \\
\text { Executive compensation committee } \\
\text { added within } 1 \text { year of beginning of } \\
\text { study (i.e., following reconstitution of } \\
\text { the board). }\end{array}$ \\
\hline $\begin{array}{l}\text { Frequency of board } \\
\text { meetings }\end{array}$ & $\begin{array}{l}\text { Once every } 2 \text { months, on average, over } \\
\text { period of study. }\end{array}$ \\
\hline $\begin{array}{l}\text { Director compensation } \\
\text { structure }\end{array}$ & Fixed annual fee. \\
\hline Firm strategy & $\begin{array}{l}\text { To produce and sell high-quality, high- } \\
\text { margin processed meat across the } \\
\text { national market. Sales-focused } \\
\text { strategy with high reliance on } \\
\text { salesforce personnel. Unionized labor } \\
\text { force, as common in major meat- } \\
\text { packing firms. }\end{array}$ \\
\hline Firm performance & $\begin{array}{l}\text { Worsening financial performance over } \\
10 \text { years preceding the study. Eroding } \\
\text { market share. Declining operational } \\
\text { efficiency relative to competing firms. }\end{array}$ \\
\hline
\end{tabular}

membership may change in response to poor performance; some members of the board may become scapegoats (Cameron, Whetten, \& Kim, 1987), whereas others may be brought in for their expertise (Hambrick \& D'Aveni, 1988). Within the literature on boards of directors, diversity is a major topic of research (van der Walt \& Ingley, 2003). Mirroring the diversity literature more broadly, it suggests that, whereas diversifying the board increases access to varied information and perspectives available for task performance, it can also impair communication, cohesion, and trust among board members (Tuggle et al., 2010). The results of that literature find similarly ambiguous effects of diversity. Boards that are diverse in terms of both demographic characteristics (Miller \& Triana, 2009) and independent outside directors (Dalton \& Dalton, 2011) have not been found to consistently exhibit higher performance. Boards, therefore, constitute an excellent context for examining our research question.

Critical to our study was the ability to observe changes in board composition. The firm's board was reconstituted to deal with financial distress by adding 10 new directors to the previously six-member board, and the board responded to the firm's worsening performance by replacing the CEO two times during the 5-year period of our study. During the second period, two of the original directors that preceded our study left the board. During the third period, one director was replaced with a new employee director, and three additional employee directors joined the board. These changes were made specifically to bring new expertise onto the board and resulted in heterogeneity of opinions and information. This enabled us repeatedly to observe patterns of interaction that followed changes in board composition as the reconstituted board dealt with a worsening financial situation over three periods.

The second reason that the board provided an excellent setting for our research is that the board in our study was positioned to exhibit both the informational and interpersonal processes predicted by the extant literature. The board could benefit from new information and interests to improve performance in the face of declining financial position. New members either joined the board at the same time as others, so that they were able to draw on a subgroup when expressing their opinion, or were high status board members such as the CEO, who were more likely to express their views. At the same time, the board was likely to experience interpersonal conflict. Four subgroups constituted the board. The firm's original six-person board of directors included two factions: "management" directors and original "outside" directors (i.e., directors not employed by the firm). Of the 10 new directors added when the board was reconstituted, 7 were outside directors (we label these "ESOP directors" to reflect the fact that they joined the board as a result of an Employee Stock Ownership Plan). The other three new directors were rank-and-file employees nominated by the local union officers ("employee" directors). Each subgroup was chosen at different points in time to represent particular interests or sources of knowledge. Furthermore, because two CEOs were replaced during the period of our study, there was the potential for subgroup status and power on the board to shift over time.

To examine dynamics in the board, we followed the approach of many organizational scholars by presenting an in-depth, longitudinal case study to allow us to develop new theoretical insights into "situations with complex dynamics and contextspecific meaning” (Cattani, Dunbar, \& Shapira, 2013: 3) and from longitudinal processes that are difficult to achieve through other research methods (Hargadon \& Douglas, 2001). Examples of this approach are Allison's (1971) classic book on decision-making, which focused on the historical case of the White House deliberations regarding the Cuban missile crisis and Weick's (1993) historical analysis of the Mann Gulch fire disaster. We studied the dynamics of the board using data collected over a 5-year period between July 1980 and December 1985. Data collection began at the point at which the board was reconstituted to the new 16-member structure. 


\section{Data and Methods}

We drew on a grounded approach (Glaser \& Strauss, 1967; Suddaby, 2006) to examine how dynamics unfolded in the board during the 5-year period. We used a longitudinal, exploratory study (Eisenhardt, 1989b; Yin, 2003), paralleling the approach of other researchers who have explored how dynamic organizational processes unfold over time with data from participant observation (cf. Clark, Gioia, Ketchen, \& Thomas, 2010; Currall, Hammer, Baggett, \& Doniger, 1999; Gioia \& Thomas, 1996). Our study was grounded in the data in two ways (Suddaby, 2006). First, our approach involved theoretical sampling to guide our choices about the unit of analysis and what data to sample from the collected dataset. Second, our approach relied on constant comparison techniques to identify important board interactions as the board integrated multiple perspectives into decisions.

\section{Data Sources and Collection}

Participant observation. The primary data for the study were the third author's participant observer notes (Evered \& Louis, 1981) from 31 board meetings held over a 5 -year period. The author had been elected to the board. There are three specific implications of the author's involvement on the board for our research approach. First, we did not enter the field with our precise research question in mind. Rather, the third author aimed to develop an understanding of both the firm's difficulties and boardroom dynamics more broadly. The changes that unfolded during the period of study allowed us to subsequently form and examine our research questions. Second, the study constituted a form of action research, in that the author was actively intervening in an attempt to help the firm and its employees improve their financial position. This further justified the researcher's presence in the organization, given the dire consequences facing the firm (Whyte, 1979). Deeper involvement also helped the researcher to learn about and grasp the firm's issues (Whyte, 1979). Second, data were collected through overt observation (e.g., Whyte, 1943, 1979). All board members were aware that the research was being conducted and could result in research publication, and they agreed to participate. It was also clear to board members that the participant observer was taking notes to capture boardroom

\begin{tabular}{l} 
Author's voice: \\
$\begin{array}{l}\text { Auw did the paper evolve and } \\
\text { change as you worked on it? }\end{array}$ \\
\hline
\end{tabular}

interactions, although that elicited very little explicit attention as most directors typically took notes during meetings.

Meetings ranged in length from 3 hours to two 8-hour days and occurred on average, once every other month. The notes consisted of verbatim accounts of board action and debate, including who spoke, on what topic, and what was said. The notes consisted of 4,428 verbal behaviors by directors and visitors, providing details about boardroom deliberations throughout the period of our study (Glaser \& Strauss, 1967). On the day following a meeting, the notes were dictated onto cassette tapes exactly as they appeared in the field notes, and the tapes were then typed into transcripts. The observer's own arguments and activities as a member of the board were also meticulously written down immediately following the meeting and supplemented with official board minutes. When meetings were especially complicated, with serious disagreements, vociferous debate, and several directors speaking at once, the participant observer supplemented the notes with copies of the unedited board minutes received from the board secretary, which were far more detailed than the official minutes.

Our unusual access to direct participant observer data provided us with deep understanding and allowed us to develop insights into complex interactions in the boardroom, informed by a fundamental understanding of the context. Focusing our data collection on first-hand observations of verbal behaviors, not retrospective accounts of what was said during board meetings, enabled us to limit the risk of mistaking participants' retrospective accounts for what was said by board members (Van Maanen, 1979). As a three-person research team, we were able to triangulate among the authors' interpretations of the data as they emerged over time (Jick, 1979). This allowed us to address potential biases of the participant observer (Spradley, 1980). To do that, the first and second authors acted as outside researchers, treating the participant observer as one of many informants in the project (Gioia, Thomas, Clark, \& Chittipeddi, 1994). Both of the other authors independently read the entire set of participant observer notes several times, developing their own emerging understanding of the board. As they began to identify key themes, the three authors met to discuss those themes, challenging and informing one another's understanding and developing hypotheses that could be checked with the data (Becker, 1958). Each of the nonparticipant authors separately and independently conducted initial analyses on the data, refining those analyses over time, and discussing emerging findings with the participant observer and each other. 
Example of a Meeting Map

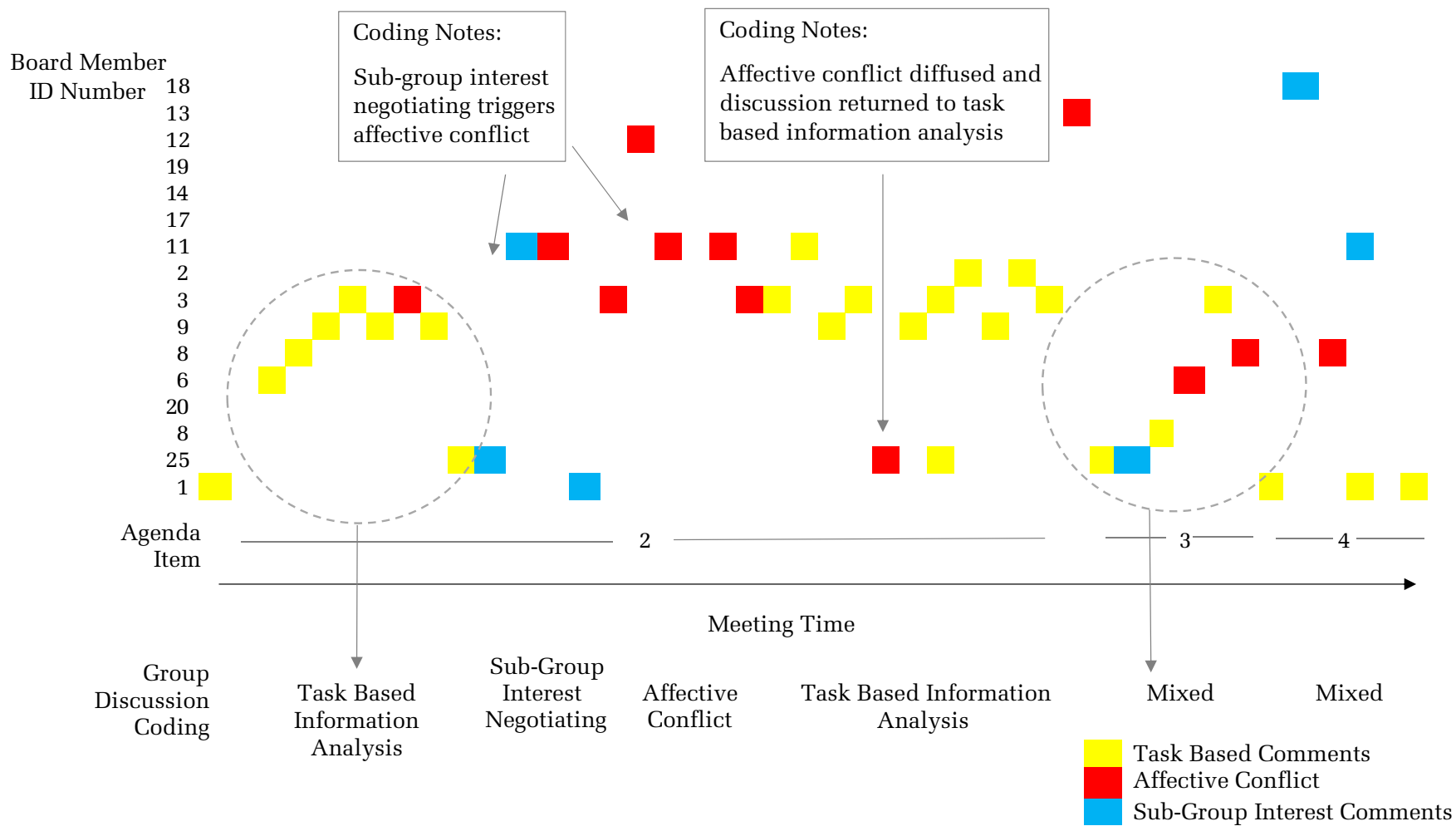

Archival data. In addition, we collected archival data such as written correspondence among board members (e.g., letters) and bankers and newspaper clippings about the firm. The archival data provided a secondary data source that added richness to the context in which dynamics played out in the boardroom and our understanding of the events and decisions of the board.

\section{Analysis}

Our analysis proceeded in three stages. In the first stage (I), we aimed to describe with precision what happened in the boardroom by content analyzing the meeting transcripts (Krippendorff, 1980). In the second stage (II), we drew on the content analysis from stage I to develop visual maps (Langley, 1999) that illustrated the chronology and nature of board member interaction over the course of each individual meeting. We label these visual maps meeting maps (Harvey \& Kou, 2013). By comparing meeting maps to identify key similarities and differences (Miles \& Huberman, 1984), we identified three stable patterns of interaction, which we discuss in detail later. In the third stage (III), we arranged the meeting maps developed in stage II along a timeline (Miles \& Huberman, 1984). This allowed us to observe how patterns of interaction responded to changes in board composition and to replicate these patterns across three time periods. We describe each stage of analysis in detail below.

Our primary unit of analysis is the boardroom interaction preceding a specific board decision (e.g., a board vote). On average, the board made six decisions per meeting. To assess those interactions, we initially focused on individual board member verbal behaviors. Subsequently, we examined how those behaviors aggregated into board interactions. Finally, we used those units to compare interactions that occurred immediately after changes in board composition with interactions that occurred when the board composition was stable.

Stage I: Content analysis. In the first stage, we performed content analysis on our field notes (Currall et al., 1999). That involved separating the verbal behaviors by board members into units and assigning verbal behaviors to the coding categories (see Guetzkow, 1950; Krippendorff, 1980). We coded directors' verbal behaviors on three dimensions: by individual, by topic, and by type of verbal contribution (e.g., statement, question, or argument). Types of verbal contributions included seeking information and making nonpersonal arguments in support of a position. Topics discussed on the board included marketing and sales projections and salesforce issues, the firm's financial 
performance, and union negotiations. In addition, each verbal behavior in the field notes was captured so that the order in which verbal behaviors occurred in the boardroom was preserved.

The content analysis began immediately after the participant observation period concluded. Beginning with a small set of verbal behavior categories based on our knowledge of the board, the participant observer (coder 1) and the second author (coder 2) selected board meetings at random and coded them, progressively expanding the coding categories when it became clear that verbal behaviors did not fit initial definitions of coding categories. Through this iterative process, we developed precise definitional boundaries among coding categories. Fifteen iterations were necessary before we had an exhaustive and mutually exclusive scheme for coding verbal behavior. To ensure that the first order codes were trustworthy (Lincoln \& Guba, 1985), we conducted rigorous tests of reliability. A graduate student with no experience either of the research site or of the development of the coding scheme independently coded three randomly selected meetings (coder 3 ). Interrater reliability estimates, computed with Scott's $\pi$ (Scott, 1955), for coders 1 versus 2 were .78 for topics and .77 for verbal contributions. The estimates of agreement between coder 3 versus coders 1 and 2 working jointly were .73 for topic and .77 for verbal contributions, indicating acceptable reliability (Nunnally \& Bernstein, 1994). The coding categories are presented in the left-hand column of Appendix A.

Once the first order codes had been developed, we grouped the codes into more abstract theoretically meaningful themes (also illustrated in Appendix A). This entailed a process of iterating between the content analysis data, our emerging interpretations, and theory until a stable set of categories remained that mutually, exclusively, and comprehensively described the data (Glaser \& Strauss, 1967; Miles \& Huberman, 1984).

Stage II: Developing meeting maps. After we established the comprehensiveness and reliability of our framework for describing the activities of board members, the next step was to examine the chronology of those behaviors within single meetings to understand team interactions. The appropriate research strategy for this is "qualitative process

Author's voice:

What was the most difficult or challenging aspect of this research project and paper? analysis" (Langley, 1999). We used the coding developed in stage I to provide a visual map of the chronology of group interactions over the course of meetings (see Harvey \& Kou, 2013 for a similar approach).

We then looked for commonalities across the meeting maps to identify similar board interactions and compare them with different interactions. We closely examined each meeting map to identify patterns of interacting. We observed that similar verbal behaviors (e.g., asking and answering questions with objective information, which were both related to objective task information exchange) frequently clustered together. Therefore, when we observed a group of similar verbal behaviors, we more closely examined the nature of discussion for key characteristics to describe the exchange, iterating with theory to understand the most relevant dimensions for explaining boardroom dynamics. We identified patterns of interaction and compared the emerging patterns with newly examined data as we went through subsequent meeting maps (Miles \& Huberman, 1984). This iterative process resulted in a stable set of three patterns of group interaction, which allowed us to compare instances where groups interacted in one pattern to instances where they interacted in a different pattern.

Stage III: Examining meeting maps over time. Given that we wanted to compare periods immediately after the board had been reconstituted with periods when the team structure was more stable, we examined how team interactions changed depending on time period. We constructed a timeline (Miles \& Huberman, 1984; Pentland, 1999) to identify times when board composition changed. Those points served as opportunities to temporally bracket (Langley, 1999) sets of interactions.

Three significant changes that occurred in board composition provided practically and theoretically relevant points at which to bracket temporal periods because they represented times at which the board composition changed, and therefore the board was injected with new perspectives, and the power structure of the board was in flux. This allowed us to replicate (Yin, 2003) the patterns of interaction that followed changes in composition of the board during three periods. Specifically, we compared the patterns of interaction leading to board decisions at the beginning of a period in which the board composition changed with the patterns leading to decisions after the board had been working together for some time. Periods of stability that emerged when the board had been working together for some time were determined by a shift in the nature of interactions that we observed. That is, we did not a priori identify time periods during which we expected board dynamics to be in flux after a change in composition; 
instead, we were guided by the data in identifying periods of change versus stability in composition. Specifically, for meetings in the middle of a time period, we examined whether the dynamics most closely matched those of early stage meetings (periods of change) or later stage meetings (periods of stability).

\section{OVERVIEW OF DYNAMICS IN THE BOARDROOM}

Observation of the board suggested that changes occurred to dynamics in the boardroom after changes in board composition. Below, we provide an overview of those dynamics in each of the three time periods we identified in our analysis. We then elaborate three types of team interactions that emerged in the boardroom, and after that, we describe how those interactions evolved over time in a systematic way.

The first period began when board composition changed to include new outside directors at the beginning of our study, creating four subgroups on the board. Before that, the board had been closed to scrutiny and was, according to the vice president of sales, a "rubber stamp" board. After the initial change in composition, the ESOP and worker directors began to question management policies and actions openly. This process surfaced new information, ideas, and perspectives. Reports at the beginning of each meeting were frequently interrupted by questions and commentaries (about hog supply, reasons for poor labor productivity figures on specific production lines, points of clarification, and so forth). That discussion was critical to helping the new directors understand the firm's core business and the source of the firm's financial distress. Interestingly, despite the time and effort needed to explain key issues to new directors, and for new directors to process that information, important decisions about financing and the scope, powers, and constitution of the board were made relatively efficiently at first.

Over time, however, discussions became longer and less likely to result in a decision. The average number of decisions dropped from eight per meeting during early meetings to four per meeting during later meetings. The deliberations were a new experience for the six original board members, who complained that meetings were longer than they

\section{Author's voice:}

Ws there anything that surprised you about the findings? If so, what? used to be, more frustrating for management, and more turbulent. In addition, leadership emerged as an important factor in that dynamic. The chairman of the board demonstrated a preference for consensus decision-making and chose, on a few occasions, to postpone decisions that threatened to be contentious, saying that he wanted to give the directors more time to consider the issue. Diversity in board members' interests became increasingly apparent during this time, and boardroom dynamics shifted toward discussions of those interests. Effectively, the heterogeneity of opinions and perspectives became an obstacle to task-focused decision making.

The arrival of CEO2 constituted a second change in board composition that marked the beginning of the second period in our study. Although the change involved only one new board member, it was significant because the CEO, of course, had substantial influence over board deliberations and that shift in control meant that each individual board member's status on the board was malleable. In addition, CEO2 was hired from outside of the board and the organization, so that existing board members had not established a relationship with CEO2 before his tenure. Board interactions followed a similar pattern following CEO2's arrival as during the first period of our study. Initially, discussions were relatively impartial and focused on expanding board members' understanding of the firm's performance. Decisions dealt with positive improvements as part of a survival plan for the firm, such as ways to improve productivity.

Over time, however, discussions became more protracted and less likely to result in a decision, with the average number of decisions per meeting dropping slightly during this period. For example, during one month, the firm sustained large losses, and the board spent several hours discussing how to manage operations. At that point, board members became frustrated with their inefficiency and ineffectiveness at improving the firm's performance. The CEO argued that there were too many board meetings (typically one per month) and too much shopfloor participation. However, he was unable to stop dysfunctional dynamics from surfacing in the board. This marked the beginning of more frequent subgroup arguments and decisions aimed at appeasing subgroup interests. Several decisions that were made this way subsequently resurfaced, and the board ultimately unmade or reversed them. For example, the board decided not to transfer the firm's trademark in one meeting, but subsequently decided to do so less than one year later.

The final period of our study was marked by the beginning of CEO3's tenure and included some additional turnover that resulted in four new employee 
TABLE 2

Examples of Team Interactions in the Boardroom

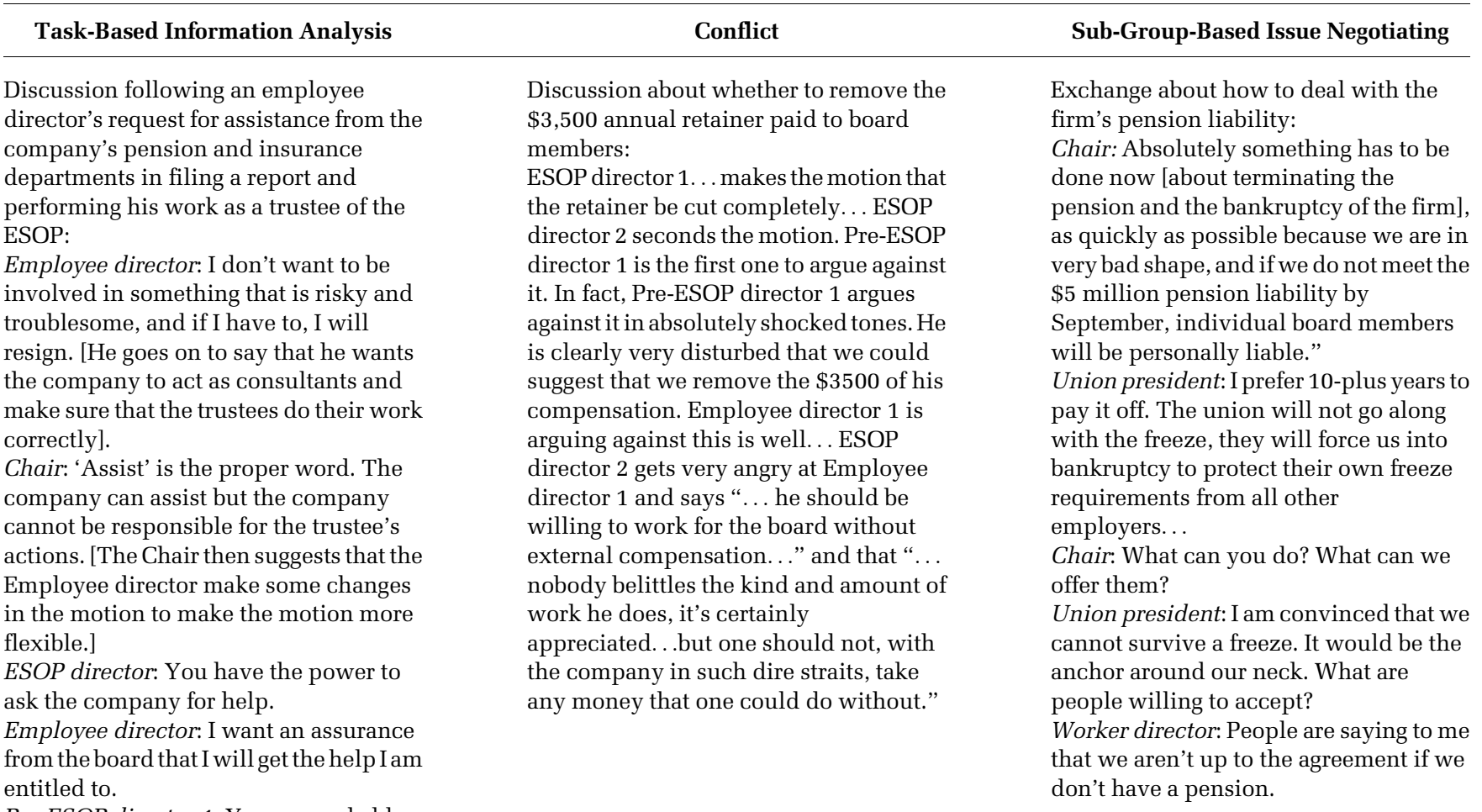

Pre-ESOP director 1: You are probably better off without my help [because it should come from outside, rather than the firm's internal attorneys].

Pre-ESOP director 2: The best help would probably be a pension consultant from the outside.

directors. CEO3 was a board member before being elected CEO. We again observed a rejuvenation of the board's focus on expanding the options to halt the financial difficulties facing the firm. For example, despite being a former head of the union, CEO3 expressed a strong interest in considering ways to take an aggressive stand against the union to improve the firm's financial position. Over time, however, those discussions too gave way to subgroup arguments and interests and the number of decisions per meeting dropped from seven to four.

We observed substantial consistency in the patterns of interaction that followed a change in composition in each of the three periods. Initially, the board would focus on the task of making decisions to improve firm performance, but over time, dysfunctional interpersonal dynamics would emerge. The chairman attempted to refocus the board. He tried to control both the agenda and the meetings with a firm hand. He told directors when to talk, stopped them from interrupting the CEO's presentations, and deflected criticisms of management performance onto himself whenever possible. However, he was unable to prevent subgroup arguments and negotiations or to redirect the board toward its urgent and critical task.

Underlying those patterns were three interrelated dynamics. First, the heterogeneity of opinions and information of board members created an information overload on the board. Second, the firm's financial crisis exerted external pressure on the board. Third, instability in the status hierarchy emerged as new relationships were forged. These dynamics shifted over time. In period 1, the information load was high as there were many new members who brought new information to the board. In period 2, CEO2 required substantial information as he came from outside of the organization, but the information requirements were less because he was the sole new board member. In period 3, CEO3 was a former board member and union president. He therefore had lower information demands than CEO2. There was some additional information load because of the addition of four new employee 
directors, although they joined an existing subgroup on the board rather than offering a fundamentally new perspective. The external pressure on the board became more intense across the three periods as the firm's financial position worsened. The board experienced a surge of optimism with each change in composition during which they perceived the crisis as less severe, but they subsequently came to recognize the firm's worsening position. With each change in composition, therefore, the degree of optimism and the persistence of task-based information analysis lessened. The extent of instability in the status hierarchy lessened across the three periods. In period 1, there were multiple new board members between whom new relationships could form; in period 2, there was one powerful outsider with whom to build relationships; and in period 3 , there was one powerful insider, so that power shifted on the board, but relationships had already been established between the new CEO and board members.

Below, we first describe the consistency we observed with each change in team composition across the three periods. We then describe how changes in the context from period to period influenced these dynamics.

\section{Team Interactions}

The boardroom dynamics described previously were characterized by three distinct types of interaction. As predicted by the literatures on team diversity, subgroups, and team turnover, we observed two types of interactions that we label task-based information analysis (which reflected informational processes described in the teams literature) and conflict (which reflected the interpersonal processes described in the teams literature). In addition, a third process that is not described in those literatures emerged, which we label subgroup-based issue negotiating. We describe each pattern in detail below. Table 2 provides examples of each approach.

Although the patterns represent clusters of similar verbal behaviors (as described in Stage II of our analysis), verbal behaviors from other categories may occasionally punctuate those interactions. For example, task-based information analysis is characterized by information exchange verbal behaviors, although one board member may make a single comment characterized by conflict within an information analysis interaction. If other board members ignored or diffused that comment and returned to information exchange behaviors, the interaction would be described as information analysis because that was the primary pattern of verbal behavior that occurred during the interaction. By contrast, if board members responded with other conflict verbal behaviors, that would mark the beginning of an interaction that fit the conflict pattern.

\section{Task-Based Information Analysis}

One form of team interaction was task-based information analysis. These interactions mirrored the informational dynamics expected to arise from team diversity and changes in team composition. During information analysis, board members exchanged and interpreted information and broadened the discussion to incorporate new factors and to introduce new possible courses of action. In general, this was done without revealing personal agendas or interpersonal conflict. When agendas or conflict did occur, the discussion quickly moved back to the task. This pattern was typical during the beginning of each of the three periods we studied. Forty-eight percent of boardroom interactions were described as task-based information analysis.

The discussion in the left-hand panel of Table 2 illustrates task-based information analysis dynamics. In this exchange, board members offered their perspectives to expand the options available for meeting an employee director's interests. Their ideas were also beneficial for the firm because they aimed to protect the firm from establishing an inappropriate relationship with the employee director. The interaction helped the board to explore potential solutions to the problem raised by the employee director. Most information analysis discussions were complex and involved a significant amount of information exchange, in particular, probing for new information to build board members' understanding. For example, in one discussion, a pre-ESOP director requested a profit-andloss statement for each product so that the board could understand the firm's financial issues. In response to his questions about how the hog-hedging operation affect the profitability of the business and whether hedging was worth the $\$ 3$ million of firm money tied up in the operation, the CEO described how hedging was used across the industry, and the union president (a visitor to the board) explained how hedging had become a problem due to a decrease in international demand for surplus meat, which now had to be sold at a loss. The pre-ESOP director continued to probe into this issue with various board members, expanding the board's understanding of the issue. Building that knowledge opened up the options available to the board, such as allowing the board to consider whether to use the hedging operation at all.

Other types of verbal behaviors occasionally punctuated discussion characterized by task-based information analysis. For example, an individual board member may react angrily to a question or 
suggestion. However, we observed that during many discussions, those reactions would be quickly contained and the board's focus remained on the task despite an occasional affective reaction.

Conflict. A second form of team interaction was the affective, interpersonal conflict described in previous literature as associated with diversity and changes in team composition. These interactions were characterized by negative interpersonal emotions and the exchange of attacks and threats between board members. This pattern tended to occur intermittently throughout the three periods in our study. Thirteen percent of boardroom interactions fell into this category.

The exchange described in the middle panel of Table 2 illustrates the conflict process. During the exchange, the outside directors directly challenged whether the employee directors were acting in the best interests of the firm. Another employee director emphasized the underlying negative emotion brought out by this discussion when she later commented:

I feel kind of separate from the rest of you [i.e., the nonemployee directors on the board] as it is anyway, and to remove my board fee would just make me feel that I was even more separated. ... It isn't as if the company is wasting a lot of money on me-it would cost them just about the same to pay me my expenses and loss of earnings.
Because of the affectively charged nature of these interactions, they tended to escalate. One discussion about the firm's financial standing, for example, became highly contentious after emotional interjections from a board member. When CEO2 indicated that, financially, the firm may have "... a pretty good month; we could even be flirting with a break-even situation," one pre-ESOP outside director, a local banker, responded: "Oh, you mean it will be a $\$ 2$ million loss rather than a \$3 million loss?” Despite CEO2's attempts to quell this conflict, others soon adopted a similar tone and the discussion degenerated.

Subgroup-based issue negotiating. Whereas task-based information analysis and conflict could be predicted from the extant literatures, we observed a third form of team interaction that emerged during boardroom discussions, which we label subgroupbased issue negotiating. During these interactions, the board developed negotiated agreements in response to subgroup interests. These discussions were dominated by arguments about the effects of alternative courses of action on special interest subgroups in the firm (e.g., employees, management, or the union), with relatively little attention to empirical data or objective information regarding the financial health of the firm. For example, executive directors tended to attempt to protect managerial compensation, whereas employee directors tended to attempt to protect employee compensation. Subgroup-based issue negotiating tended to occur midway through

FIGURE 1

\section{Patterns of Interaction over Time}

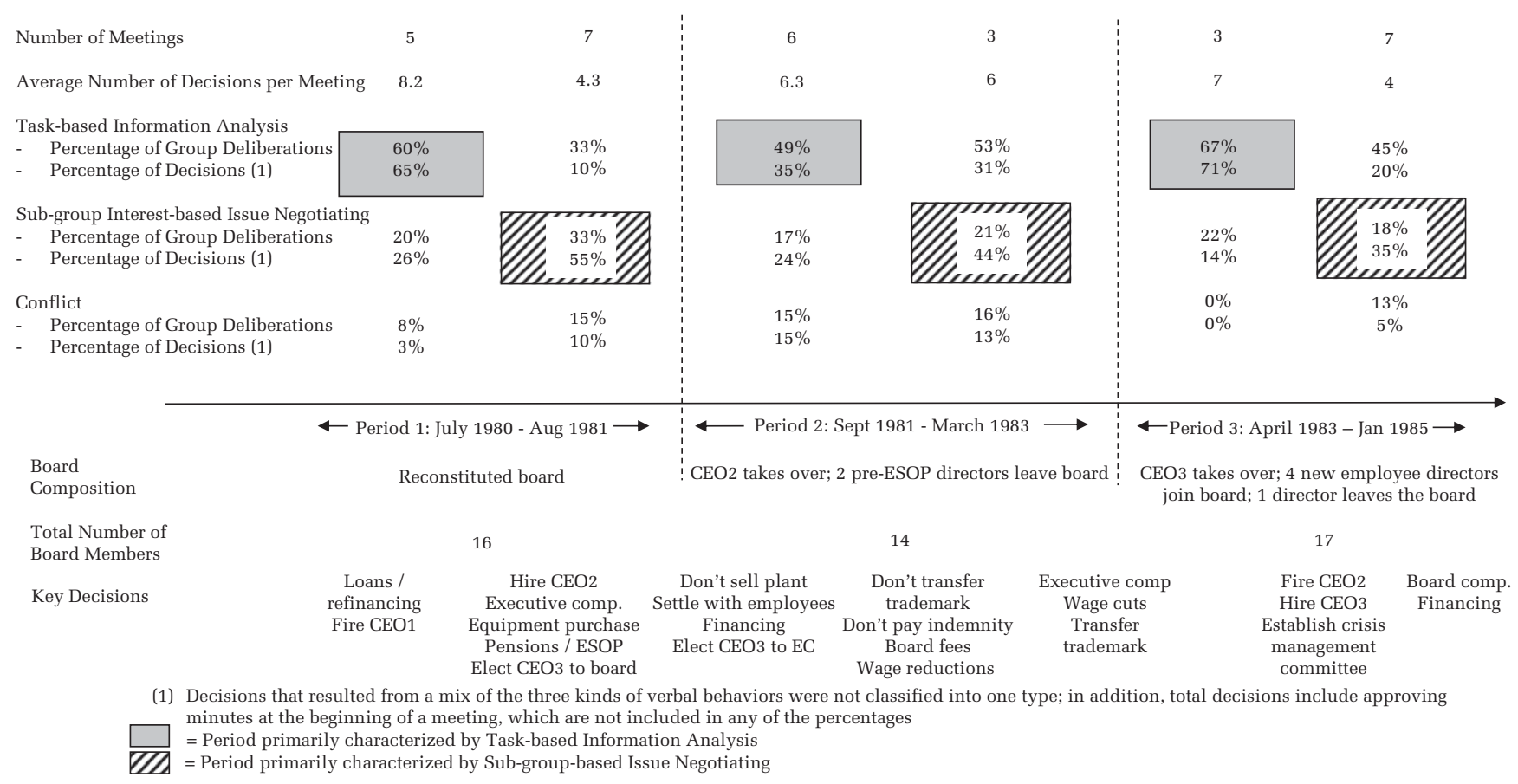


each of the three periods in our study. Twenty-one percent of interactions fell into this category.

The exchange in the right-hand panel in Table 2 illustrates the issue negotiating approach. During the discussion, the board attempted to determine the best strategy for dealing with the pension liability by considering how individual board members, the union, and employees would be affected by, and react to, different strategies. The example illustrates that board members attempted to gather information on and understand one another's perspectives during these discussions, such as when the union president probed for information on what the employees would accept. As opposed to focusing on what might have been in the financial best interests of the firm, however, the chair emphasized resolving conflicting subgroup interests when he asked, "What can we offer [the union]" in exchange for going along with the strategy?" Interpersonal conflict sometimes accompanied these discussions, but that conflict was often quickly diffused. Where it was not, negotiating discussions tended to be followed by conflict.

\section{Temporal Patterns of Boardroom Interactions}

We further observed that the board engaged in the three types of team interactions in a predictable pattern over time. Specifically, following a change in composition, the board first engaged in task-based information analysis then moved to subgroup-based issue negotiation. The pattern is illustrated in Figure 1. To describe that pattern, we draw on two descriptive statistics from our findings-the percentage of interactions classified by different types during early versus later stage meetings after a change in board composition, and the percentage of decisions preceded by a type of interaction during early versus later stage meetings. In general, we observed that fewer interactions were classified as task-based information analysis and more interactions were classified as subgroupbased issue negotiating in later stage versus earlier stage meetings after a change in composition (see Figure 1). Importantly, we also observed that the likelihood of a decision following information analysis decreased during later stage meetings compared with early stage meetings, and the likelihood of decisions following an issue negotiating interaction increased during later stage compared with early stage meetings (see Figure 1). We suggest that those broad trends indicate a shift in the basis on which board members were able to reach consensus and therefore reflect a shift in the dynamics of the board, both in terms of decisionmaking and interpersonal processes. We describe the pattern in more detail across the three periods below.

Following a change in composition, the board oscillated between periods of task-based information analysis and periods of subgroup-based issue negotiating, with conflict occurring intermittently throughout. This pattern suggests that initially, a change in composition stimulated discussion of the root causes of the firm's difficulties and introduced new options for the board to consider. At the beginning of each period in Figure 1, boardroom interactions were characterized primarily by taskbased information analysis. Importantly, the decisions (i.e., votes) that were made during these periods followed information analysis. Over time, however, board interactions became dominated by subgroup issue negotiating. Moreover, when those interests were discussed, decisions appeared to become easier for the board to reach. As Figure 1 illustrates, toward the end of each period, decisions were more likely to be preceded by subgroup interest-based negotiating than by information analysis. For instance, in period 1, although only 33 percent of boardroom deliberations involved subgroup-based issue negotiating, those interactions preceded 55 percent of the decisions made, whereas information analysis preceded only 10 percent of decisions. Similarly, toward the end of period 2, issue negotiating preceded 44 percent of decisions, and toward the end of period 3 , issue negotiating preceded 35 percent of decisions.

One of the board's most significant early decisions occurred in period 1 and relied on sub-group-based issue negotiating. The stock ownership agreement between the firm and its employees included the replacement of the CEO1. Although the CEO1 continued to run the firm for 9 months after the ESOP began, he knew he was only a caretaker and left the operations of the board to the chairman. The board therefore had to select a new CEO. Only one candidate for the position was seen as having a compelling plan for turning the firm around. Surprisingly, however, board members objected to that candidate's plan because of the potential impact on various constituents (e.g., the union). As a result, that candidate was not hired, and a candidate who provided more of a compromise between conflicting subgroup interests became CEO2. The financial position of the firm continued to worsen after CEO2 was hired.

\section{Shifts from Task-based Information Analysis to SubGroup-Based Issue Negotiating}

To better understand why a pattern of shifting from task-based information analysis to subgroupbased issue negotiating may have occurred, we 
examined the meeting transcripts for those points at which issue negotiating first became the dominant form of interaction preceding board decisions. This revealed that information analysis interactions could lead the board to divert their discussion toward issue negotiating. ${ }^{2}$ In particular, the board displayed a tendency to delay decision-making on some issues because they lacked an understanding of the financial information necessary to reach a decision. At that point, board members would move the discussion forward by making arguments for satisfying particular subgroup interests in the absence of the ability to make a more objective, financially focused decision.

An example of the shift from information analysis to issue negotiating occurred during a meeting in February 1982, part way through CEO2's tenure. That discussion began with task-based information analysis when board members discussed whether the firm should be shrinking its inventories. The labor representative (the local union president, a visitor to the board) commented that "...this is a problem, because we can really do two things-we can lay-off people and we can discount the price. If we discount the price, we're going to lose money; if you lay off people, people are going to be upset." Various board members then probed to understand the amount of inventory held by the firm and the implication of reducing inventory for firm performance. After the union president argued in favor of buying inventory from other firms instead of continuing to run the "kill-line" (through which inventory was produced), CEO2 commented that “... we cannot do this too fast ... we have so many changes going on at once." At that point, several board members emphasized the simple need for action, with the Labor Relations Officer concluding that “. . he doesn't really want to stop the kill, but he wants to do something." Despite the fact that a decision about the best option was never reached, the discussion transitioned onto how to get the firm's employees and union to support board initiatives. That discussion relied heavily on subgroup-based issue negotiating, with different members drawing on arguments in support of worker, union, and management interest. At that point, the discussion had been diverted away from the best course of action for the firm and toward how to implement any

\footnotetext{
${ }^{2}$ Engaging in conflict interactions could also produce discomfort and make it difficult for the board to reach a decision due to interpersonal conflict. We focus here on the shift from information analysis to issue negotiating because that was the primary pattern we observed in our data, as illustrated in Figure 1.
}

course of action, given the need to do something and the knowledge that all decisions would be difficult.

As a second example, the fourth meeting of the reconstituted board and the point at which the predominant board dynamic began to shift from information analysis toward issue negotiating also illustrates this pattern. During the discussion, the board attempted to understand why the union was upset about financial information they had received from the board. ${ }^{3}$

ESOP director 1 brings up the question of what happened to the $\$ 5$ million held in escrow. The VP of Finance is calm and explains what happened in clear, even language... ESOP director 1 then turns to CEO1 and says there are a couple of things about the figures that he does not understand. [An exchange about the figures follows between the VP Finance, ESOP director 1, and ESOP director 2]. CEO1 does not respond [to ESOP director 1's questions]; the chair answers for him, and preESOP director 1 [a banker] chimes in from time to time.... ESOP director 2 says "I would like to know why the misunderstanding came about, and in particular, why do I end up getting calls from the union about this, when they should have gotten the response straight from management?" CEO1 and the VP of Sales and Marketing are both defensive about this question; CEO1 stops speaking completely. ESOP director 1 says "What do you expect these guys to believe if they can't even understand the figures you presented?" The chair turns to ESOP director 1 and ESOP director 2 and takes full blame for this misunderstanding, saying it was probably the board's fault or his fault and that he's sorry this happened. The CEO continues to say that the union got a full explanation of what happened to the money that nothing was withheld from them.

During this part of the exchange, the board interaction was characterized primarily by information analysis. The board began by trying to understand financial information that had been presented to the union and the cause of the union's confusion over that information. The ESOP directors attempted to expand the board's perspective by reframing the issue in terms of the union's position and their own involvement in resolving the issue. However, the ESOP directors' probing led management to withhold information about the issue, and the board chair to take responsibility for the problem without the board really understanding its root causes.

\footnotetext{
${ }^{3}$ Names of directors have replaced by descriptive role positions
} 
Accepting responsibility had the unexpected effect of beginning to divert the board away from information analysis because no alternative solutions could be identified without a deeper understanding of the issue. Following the previous excerpt, ESOP director 1 raised an issue about a change in how pensioners were getting access to medical insurance. ESOP director 1 indicated that this may not be an appropriate issue for the board, noting that he "... does not want to bring collective bargaining issues to the board" and two of the other outside directors expressed similar concerns that the issue was petty and should be dealt with by management, not the board. The board discussed the issue in some depth despite that, with directors strongly advocating for different interest groups (the union versus management). Ultimately, the board resolved this issue when the chair asked the Labor Relations Officer (a visitor to the board) to look into getting help for the pensioners at a low cost. The board's attention was therefore diverted away from a significant and complex problem with the union, the resolution of which may have improved management-labor relations. The board then discussed a more minor issue that did not require a prolonged discussion of underlying causes and detailed financial figures and was therefore easier for the board to resolve.

In a third example, the chairman of the board introduced an immediate need to make a decision about the pension plan to comply with Internal Revenue Service regulations. The firm lacked the funds to make a necessary payment of $\$ 1.8 \mathrm{M}$ to the IRS, but would need to make the payment or face a further financial penalty or directors' personal liability for the payment. In considering a variety of options, including whether to freeze or terminate the pension plan, various board members advocated specific ideas, but the discussion subsequently turned to what other concessions the firm could obtain from workers, as a way to achieve better financing terms and protection from creditors.

During this discussion, the union president (now a member of the board) shifted the framing of the discussion to the subgroup interests of the union. He responded: "I prefer 10-plus years to pay it [the money] off. The union will not go along with the freeze..." The chair then asked "What can you do? What can we offer them (the union)?", and the discussion moved toward how to satisfy the union rather than how to deal with the pension issue. Although one of the auditors eventually took over to objectively discuss the benefits and disadvantages of filing for Chapter 11, the board as a whole never completely shifted back toward the task. There was no clear resolution to the discussion, with board members after the meeting expressing different understandings of the best way to deal with the situation, and having different preferences for freezing the pension plan, terminating the pension plan, and filing for Chapter 11 .

\section{Effect of Underlying Dynamics on Team Interactions}

At the heart of those points at which board discussion diverted away from information toward subgroup interests were three interrelated dynamics. First, the heterogeneity of opinion and information created complexity that itself formed an obstacle to effective task-focused decision making. In the first example above, ESOP director 1 stated that there were some figures he did not understand. In the second example, CEO2 subsequently commented that he could not understand why money had not been moved from one bank charging a high interest rate to another where it could be consolidated with other firm funds, and ESOP director 2 noted that she was "...so totally confused in terms of who [one of the lenders] is that they seem like nothing but a bunch of shysters." Therefore, the board's difficulty understanding complex issues because of the breadth of information available was associated with boardroom deliberations shifting away from those topics.

Second, the firm's worsening financial position further intensified the complexity created by the information load. As the firm's financial problems became more urgent, the board came to realize that they did not fully understand the nature of the problems they were facing and felt under even greater pressure to take immediate action to solve those problems. Board discussions reflected the external pressure to act due to the firm's financial position, such as when the Labor Relations Officer indicated a desire "to do something," as in the first example above. Similarly, in the third example above, there was an urgent need to act on the pension issue. When the board could not immediately resolve that issue, they turned to a subgoal that may have helped them move toward resolving the pension problem-how to satisfy the union to allow them to take action. Whereas the diversity of information and opinion shifted the board away from complex financial issues, external pressure moved the discussion toward a relatively simpler negotiation of divergent interests.

Third, the instability of the status hierarchy after a change in board composition emerged as an alternative basis for decision-making. During discussions, a variety of positions were revealed that suggested short-term subgoals on the path to improving 
financial performance that the board could pursue. For instance, in the third example above, the union president said that the union would not allow the board to freeze the pension plan, so satisfying the union became an alternative problem for the board to solve. That was possible because of instability in the status hierarchy-in this instance, the increasing influence of the union and workers. Furthermore, instability in the status hierarchy contributed to the difficulty of resolving the confusion created by the information load. In attempts to retain or gain status, board members engaged in conflict and influence tactics such as stonewalling (i.e., refusing to answer a direct question). For example, CEO1 frequently refused to answer questions about the financial position of the firm to avoid revealing his own role in the firm's financial situation, and CEO2 frequently refused to answer questions about his plan to save the firm to avoid revealing his lack of understanding of the full financial situation. Status hierarchies can help teams to coordinate their behaviors (Halevy, Chou, \& Galinsky, 2011). Without a clear hierarchy, however, it may have been difficult for board members to compel or coerce one another to share information.

The chairman of the board was unable to halt the shift from information based discussions to subgroup negotiations, despite attempts to direct board discussion. One reason may be that the chair had a preference for consensus and as a result often accepted blame for problems. Ironically, that may have prevented the board from getting to the root of those problems and therefore from making decisions on issues directly related to their core goals. The chair's drive for consensus may also have directly contributed to the board's satisfaction with resolving subordinate goals. In addition, the chair employed a participative and distribute leadership approach, giving substantial responsibility to other board members. That may also have allowed board members to surface their subgroup interests, creating the opportunity for interest-based negotiating. Therefore, although we do not suggest that leadership created the dynamics we observed, a more effective leadership style may have prevented the shift from information to interest-based negotiating.

\section{Summary: Decision Diversion and Team Performance}

We summarize the process observed in the board in Figure 2. We label it decision diversion, a process through which the board gradually shifted their goals

FIGURE 2

\section{Summary of the Process of Decision Diversion Observed Inside a Corporate Boardroom}

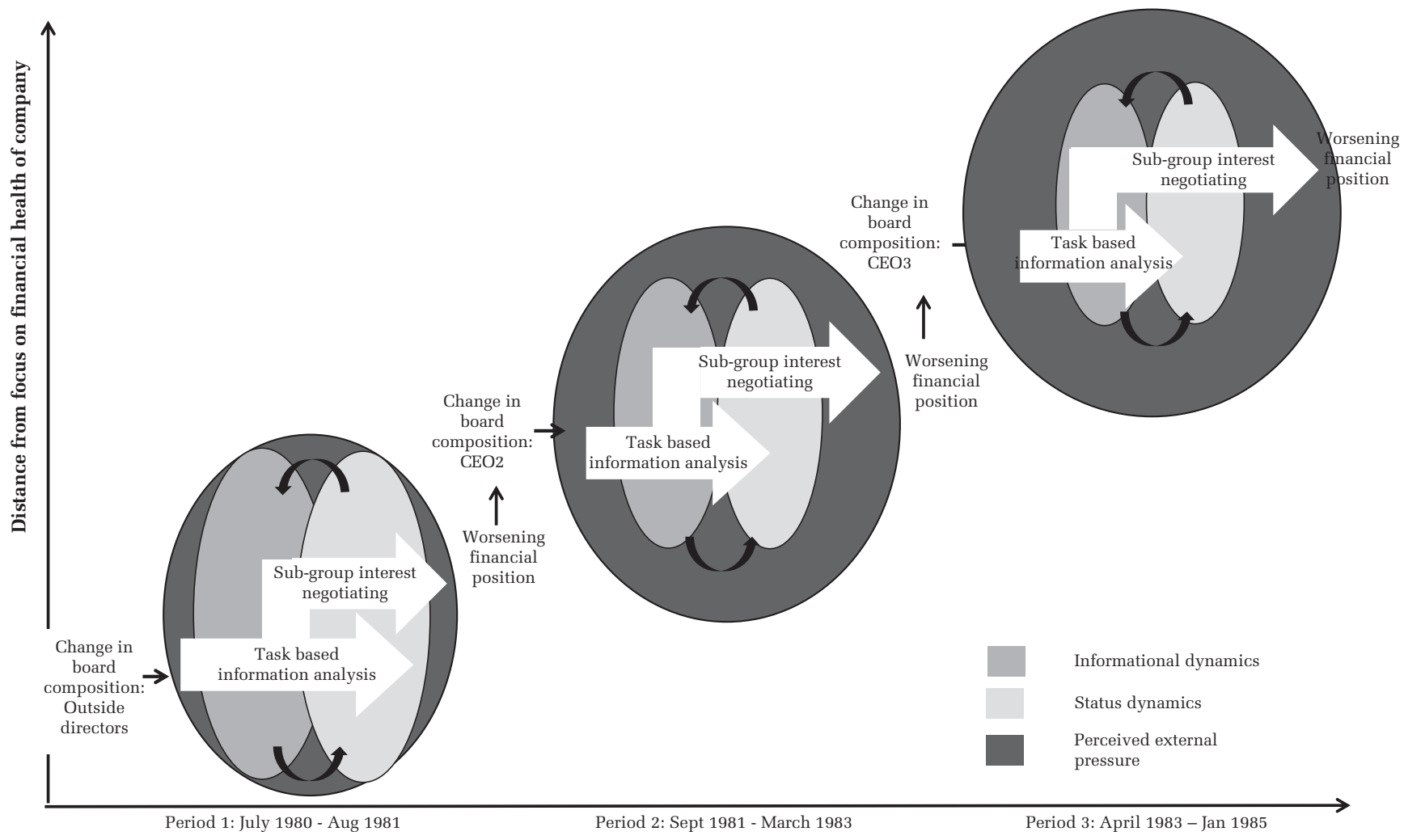


away from improving the financial performance of the company over time. The process involves a pattern of board deliberations shifting from information analysis to subgroup issue negotiating, resulting in a shift in the very goals the board was attempting to pursue. Over time, decisions based on the board's fiduciary responsibility to the firm were displaced by decisions based on the subgroup interests of board members, which were seen as opportunities to overcome obstacles on the path to improving the firm's financial performance. For example, instead of attempting to make a choice in the best interests of the firm, the board may have chosen an alternative that they knew would boost workforce morale in exchange for employee cooperation with something else.

Underlying this pattern was a confluence of informational, status, and external dynamics. ${ }^{4}$ A key insight is that this problem was intensified by the board's attempt to expand the discussion to incorporate new information and introduce alternative courses of action through task-based information analysis. That heterogeneity of opinion created an obstacle. Information analysis highlighted the complexity of the problems facing the board and may have made the problems themselves appear intractable. Coupled with the heightened need to make a correct decision because of the importance of strategic decisions for the firm's financial viability, new information, and alternative courses of action made it difficult for the board to reach consensus. Over time, information analysis gave way to decisions that could be reached by negotiating various subgroup interests. Those decisions were aimed at satisfying fundamentally different goals than the board's core task of regaining financial stability. Subgroup issue negotiating emerged as the team members learned about, and came to understand, one another's goals and interests. The board chair was unable to refocus the board's attention on its core task.

We posit that decision diversion resulted in suboptimal decision-making because it typically involved the discussion of issues that board members themselves considered to be less important than the firm's survival, it occurred when board members were confused and had difficulty reaching a decision, and it was associated with the continued worsening of the firm's financial performance. We further posit that decision diversion emerged from changing team composition in an environment of poor financial performance and that it contributed to

${ }_{4}$ These dynamics are represented by grey circles in Figure 2. External pressure increased over time, whereas informational and status dynamics lessened. the firm's worsening performance. This is because financial distress brings the trade-off between decision quality and decision-making efficiency into sharp relief; when a firm faces financial distress, the board's decisions are critical for the firm's survival and must be high in quality and the pressure to make those decisions is acute. The context prompts the team to take action.

The process of decision diversion relates to, but is distinct from, several concepts previously described in organizational literature. As we may have expected, subgroups or factions (Carton \& Cummings, 2012; Lau \& Murnighan, 1998; Li \& Hambrick, 2005) developed in the board and board attention turned toward negotiating the interests of those subgroups. What was surprising was that subgroup dynamics only came to dominate team interactions after the failure of task-based information analysis. In the short term, the team focused on task-based information analysis, and conflict occurred infrequently and in relative isolation. By contrast, the literature on diversity and subgroup dynamics suggests that the interpersonal consequences of team composition occur shortly after team formation and focuses on avoiding or managing conflict as necessary interventions in diverse teams (Li \& Hambrick, 2005; Pelled, Eisenhardt, \& Xin, 1999). During the process of decision diversion, board members reached the limit of their ability to process all of the information relevant to a decision (Cyert \& March, 1963) and may well have experienced information overload (O'Reilly, 1980). What was unexpected, however, was that the board became overwhelmed with information relatively quickly after a change in composition. Research on team composition and membership change would suggest that those informational effects emerge over time and as a result of poor interpersonal processes (Srikanth et al., 2016). Finally, decision diversion is similar to satisficing (Simon, 1957). However, rather than choosing an acceptable alternative instead of an optimal alternative, the board in our study chose to respond to an overwhelming amount of information and complexity of information by shifting its attention to pursuing entirely different goals.

\section{Boundaries of the Study}

Our empirical findings, and the process resulting from them, provide a window into how team dynamics may unfold following a change in team composition. The nature of the team in our study, a corporate board, was critical to enabling us to examine those dynamics. The team underwent several changes in composition specifically to deal with poor 
TABLE 3

Summary of Discoveries

\begin{tabular}{|c|c|}
\hline Summary of Prior Research & Our Discovery \\
\hline $\begin{array}{l}\text { Interpersonal conflict and } \\
\text { sub-group dynamics are } \\
\text { at the root of problems for } \\
\text { diverse teams and changes } \\
\text { in team composition }\end{array}$ & $\begin{array}{l}\text { Interpersonal conflict and sub- } \\
\text { group dynamics emerged } \\
\text { over time following the } \\
\text { breakdown of task-based } \\
\text { information analysis }\end{array}$ \\
\hline $\begin{array}{l}\text { Informational diversity is } \\
\text { beneficial for teams who } \\
\text { can overcome their } \\
\text { interpersonal issues }\end{array}$ & $\begin{array}{l}\text { Difficulty analyzing } \\
\text { information for decision } \\
\text { making is at the root of some } \\
\text { diverse team problems }\end{array}$ \\
\hline $\begin{array}{l}\text { Attempting to understand } \\
\text { and integrate one another's } \\
\text { perspectives leads to } \\
\text { effective decision-making }\end{array}$ & $\begin{array}{l}\text { Attempting to understand and } \\
\text { integrate one another's } \\
\text { perspectives can lead to the } \\
\text { emergence of alternative } \\
\text { bases for decision-making } \\
\text { (decision diversion) }\end{array}$ \\
\hline
\end{tabular}

organizational performance; the team was therefore well positioned to benefit from diverse information and interests. That allowed us to examine how dynamics described in previous literature could unfold, and specifically, how that process was triggered by a change in composition.

However, changes in team composition also bound our findings in two important ways. First, our findings are more likely to apply in those contexts in which team composition is altered to improve poor team performance than in contexts where team composition is changed during times of good performance. Teams that change composition during periods of good performance seem less likely to exhibit the same pattern. We speculate that changing composition may also be less likely in that context. Second, our findings are more likely to apply to situations in which new members are relatively high in status, take on a high status role in the team, or belong to a subgroup than situations where a single low status team member joins the team. When lone new members who are not high in status join a team, they are more likely to conform to the team's decisions, which would not trigger the dynamics we observed. In general, we are not able to disentangle the effects of external context, informational dynamics, and status dynamics from compositional effects in our data; we can only describe the processes we observed in the presence of these dynamics.

Given our emphasis, several other factors are not included in the decision diversion framework. For example, although our framework has implications for the effects of diversifying teams, these implications are separate from how the amount of diversity on the team (e.g., proportion of women) affects firm performance. Furthermore, although we consider how board decisions sustained the firm versus exacerbated the firm's financial distress, our data do not allow us to be decisive in identifying the financial outcomes of specific board decisions, nor can we pinpoint which decisions were primarily responsible for the firm's eventual bankruptcy.

\section{IMPLICATIONS FOR UNDERSTANDING CHANGES IN TEAM COMPOSITION}

Our study began with the observation that the advice to change team composition to improve team decision-making is implied by the team diversity literature. Literatures on team diversity, subgroups, and team turnover suggest that changing team composition may disrupt team interpersonal processes but should improve team information processing. Our findings are consistent with previous diversity research that finds both informational and interpersonal effects of diversity on team performance (Milliken \& Martins, 1996; van Knippenberg \& Schippers, 2007). Over the long term, both information processing and interpersonal relations in the board in our study became problematic. However, we also observed an alternative process through which those effects may occur, thereby offering new directions for research. We summarize our key discoveries in Table 3.

\section{Challenging Assumptions and New Directions for Research}

Emergence of interpersonal and subgroup dynamics. Much existing literature portrays diverse teams as characterized by a high degree of conflict and a lack of genuine, task-focused communication (van Knippenberg \& Schippers, 2007; Williams \& O'Reilly, 1998). In teams with subgroups, team dynamics can be even more dysfunctional (Lau \& Murnighan, 2005; Li \& Hambrick, 2005). Interpersonal attraction and subgroup formation are expected to occur quickly after the formation of a team (Brewer, 1979) and are viewed as problems to overcome to achieve outstanding performance. Although we observed that individual team members on the board we studied pursued personal and subgroup agendas through the application of interpersonal tactics including conflict, those attempts often occurred in isolation and were typically quashed by the board. We suggest that, whereas the behaviors of individual team members may be well described by existing research on diversity and subgroups, further research is necessary to explain how those individual behaviors translate into team dynamics.

Our findings reveal a more gradual emergence of poor interpersonal processes over time. Initially, team members used one another's affiliations as a way to understand their interests and positions, consistent with the notion that salient surface level 
differences between team members can signal the presence of deeper level differences in information and perspective (Phillips et al., 2004; Rink \& Ellemers, 2006). One explanation for that effect is that members of diverse teams are less focused on building relationships with one another (Loyd et al., 2013). We similarly observed a strong task focus immediately following changes in board composition. Interpersonal problems occurred after a breakdown in task-based information processing. This opens up the question of how researchers should conceptualize the order of the informational versus interpersonal effects of diversity over time and adds to recent calls to more closely examine the role of time in diverse teams (Harrison, Price, \& Bell, 1998; Mohammed \& Harrison, 2013; Srikanth et al., 2016). In particular, we highlight two questions for further research. One question is what are the immediate effects of a change in team composition on information processing in teams? In particular, research in this vein may examine how dimensions of a team's task, including urgency and importance, may influence information processing. A second question is how do those effects influence the emergence of interpersonal effects over time? That research should consider how failures in decision making, or failures to make decisions, may shape subsequent interpersonal interactions.

Information as a root of problems after changes in team composition. In our study, the diversity of perspectives represented on the board, and their associated information processing demands, emerged as the heart of poor decision-making. The primary failing of the team in our study was one of information analysis and decision-making - the board ended up preserving decision efficiency (i.e., the tendency to reach some type of decision, in fact, any type of decision) at the expense of decision quality (as defined by focusing on the firm's financial viability). This finding stands in contrast to the dominant model of diversity, which views informational problems as resulting from interpersonal dynamics. Our findings are consistent with emerging evidence that it is challenging for diverse teams to effectively integrate the information that team members bring to deliberations information (Dahlin et al., 2005; Srikanth et al., 2016).

The challenge of integrating information in the context of status instability and external pressure often led to difficulty in reaching a decision. Failure to make decisions has generally been overlooked as a source of difficulty for diverse teams (Denis, Dompierre, Langley, \& Rouleau, 2011; Nijstad \& Kaps, 2008). Our study demonstrates how failure to reach decisions may provide an opportunity for an alternative basis for decision-making to arise. In doing so, our study opens up a series of avenues for further research. It raises the question of what types of obstacles to effective decision making occur as a result of diversity. Specifically, how does the content of team members' interests and opinions combine to create obstacles? Our research calls for further attention to the process through which diverse teams choose which goals to pursue and in particular, how they can become diverted away from high-level, broad, important goals to focus on smaller, more manageable problems. It also suggests that further research is needed on how teams can effectively cope with large amounts of complex information.

One key issue within that process is the role of leadership. Leaders may play a critical role in keeping diverse teams on track. How might effective leadership of diverse teams with changing composition differ from more traditional leadership models? Our findings suggest that the participative, inclusive form of leadership that is often advocated as beneficial for team performance (e.g., Edmondson, 1999) may be less effective for diverse teams facing high levels of informational complexity and external pressure. In that context, effective leadership may require directing a team's attention towards core goals, which may entail limiting participation on some issues. A key question for future research is: how can leaders help diverse teams to maintain their focus on distal but important goals? Further, research may consider whether leaders' effectiveness at achieving that task can be monitored, particularly within the context of a corporate board.

Perils of understanding and integrating perspectives. In our study, it was the team's attempt to act in pursuit of performance on the task that led to decision diversion. This stands in contrast to the widely held belief that diversity benefits groups when members explore and accept alternative perspectives (Ely \& Thomas, 2001; Hambrick, 2007; van Knippenberg \& Schippers, 2007). Instead, we build on a developing view that in some cases it is unnecessary and even suboptimal for group members to resolve their underlying differences (e.g., Gillespie, 2011; Majchrzak et al., 2012). Sub-group interest negotiating enabled team members and sub-groups in our study to resolve differences, yet because it provided a more straightforward basis for decision-making, it allowed the team to replace their core goal of improving the firm's financial health with sub-goals that moved them increasingly further away from that core goal.

Our study reveals issue negotiating as a third possible path to team decision-making. Previous research may have characterized issue negotiating as either a decision-making process or an interpersonal process, but we describe it as a distinct process because it is neither an attempt to make 
a good decision in the service of task performance, nor a political process in which team members attempt to pursue their own sub-group agendas. Similarly, it differs from satisficing (Simon, 1957), in that it is not a choice to accept a sub-optimal alternative. Rather than poor decision-making, issue negotiating emerges because a team chooses the wrong type of decision to make. Yet, the decisions a team makes while issue negotiating are still attempts to serve the team task rather than team members' own personal agendas. Research on goal displacement (Kerr, 1975; Merton, 1957) similarly suggests that intangible high-level organizational goals can become subordinated to more proximal and measurable goals when decision-makers need to act and become frustrated with abstract goals (Warner \& Havens, 1968). In our study, the board viewed resolving sub-group interests as steps on the path towards their core goal. However, pursuing those steps ultimately diverted them from that core goal.

Our study suggests several directions for future research in this area. One is to consider the conditions under which understanding and integrating perspectives may be helpful versus detrimental for diverse team performance. How does the precise team composition influence that balance? For example, perhaps integrating perspectives becomes problematic when team members' interests are too divergent. Alternatively, how does the decision-making context influence that process? Integrating perspectives may become more challenging when teams are under extreme pressure. Finally, perhaps some processes are effective for integrating perspectives whereas others are not. Therefore, another important question for further research is to examine how diverse teams can resolve differences in interests without diverting attention away from core goals.

\section{CONCLUSION}

In unraveling the precise processes through which changing team composition influences team interactions, we have identified dynamics that may be counter-intuitive in light of traditional social psychological research on group and interpersonal processes. Importantly, it is the combination of adding new members, in the context of poor team performance and when decisions are important and urgent that leads to decision diversion in our model. That implies that a natural limit may exist to the effectiveness of manipulating team composition as a mechanism for improving decision-making because any turnover that occurs during periods of poor performance may lead to, or exacerbate, decision diversion.

Decision diversion was revealed by studying a team's continuous interactions over time in a real field setting. Indecision, subgroup dynamics, and boardroom interactions are difficult to assess through post hoc survey, interview, or archival research. Clearly, those methods are indispensable, yet the phenomena that we have highlighted in this study have underscored the advantages of direct observation to more fully understand team processes. Our research indicates a need to consider the dynamic processes through which team composition influences decision-making, rather how it operates as a fixed input into decisions.

\section{REFERENCES}

Allison, G. 1971. Essence of decision: Explaining the Cuban Missile Crisis (1st ed.). Boston: Little Brown.

Ancona, D. G., \& Caldwell, D. F. 1992. Demography and design: Predictors of new product team performance. Organization Science, 3: 321-343.

Ariño, A., LeBaron, C., \& Milliken, F. J. 2016. Publishing qualitative research in Academy of Management Discoveries. Academy of Management Discoveries, 2: 109-113.

Bantel, K., \& Jackson, S. 1989. Top management and innovations in banking: Does the composition of the team make a difference? Strategic Management Journal, 10: 107-124.

Becker, H. S. 1958. Problems of inference and proof in participant observation. American Sociological Review, 23: 652-660.

Bezrukova, K., Jehn, K. A., Zanutto, E. L., \& Thatcher, T. 2009. Do workgroup faultlines help or hurt? A moderated model of faultlines, team identification, and group performance. Organization Science, 20: 35-50.

Brewer, M. B. 1979. In-group bias in the minimal intergroup situation: A cognitive-motivational analysis. Psychological Bulletin, 86(2): 307.

Cameron, K. S., Whetten, D. A., \& Kim, M. U. 1987. Organizational dysfunctions of decline. Academy of Management Journal, 30: 126-138.

Carton, A. M., \& Cummings, J. N. 2012. A theory of subgroups in work teams. Academy of Management Review, 37(3): 441-470.

Cattani, G., Dunbar, R. L. M., \& Shapira, Z. 2013. Value creation and knowledge loss: The case of Cremonese stringed instruments. Organization Science, 24: 813-830.

Chatman, J., \& Flynn, F. 2001. The influence of demographic heterogeneity on the emergence and consequences of cooperative norms in work teams. Academy of Management Journal, 44: 956-975.

Choi, H. S., \& Thompson, L. 2005. Old wine in a new bottle: Impact of membership change on group creativity. Organization Behavior and Human Decision Processes, 98: 121-132. 
Clark, S. M., Gioia, D. A., Ketchen, D. J., \& Thomas, J. B. 2010. Transitional identity as a facilitator of organizational identity change during a merger. Administrative Science Quarterly, 55: 397-438.

Cronin, M. A., \& Weingart, L. R. 2007. Representational gaps, information processing, and conflict in functionally diverse teams. Academy of Management Review, 32: 761-773.

Currall, S. C., Hammer, T. H., Baggett, L. S., \& Doniger, G. M. 1999. Combining qualitative and quantitative methodologies to study group processes: An illustrative study of a corporate board of directors. Organizational Research Methods, 2: 5-36.

Cyert, R. M., \& March, J. G. 1963. A behavioral theory of the firm. Englewood Cliffs, NJ: Prentice-Hall.

Dahlin, K. B., Weingart, L. R., \& Hinds, P. J. 2005. Team diversity and information use. Academy of Management Journal, 48: 1107-1123.

Daily, C. M., \& Dalton, D. R. 1992. The relationship between governance structure and corporate performance in entrepreneurial firms. Journal of Business Venturing, 7: 375-386.

Dalton, D. R., \& Dalton, M. 2011. Integration of micro and macro studies in governance research: CEO duality, board composition, and financial performance. Journal of Management, 37: 404-411.

Denis, J. L., Dompierre, G., Langley, A., \& Rouleau, L. 2011. Escalating indecision: Between reification and strategic ambiguity. Organization Science, 22: 225-244.

Earley, C. P., \& Mosakowski, E. 2000. Creating hybrid team cultures: An empirical test of transnational team functioning. Academy of Management Journal, 43(1): 26-51.

Eisenhardt, K. M. 1989a. Agency theory: An assessment and review. Academy of Management Review, 14: 57-74.

Eisenhardt, K. M. 1989b. Building theories from case study research. Academy of Management Review, 14: 532-550.

Edmondson, A. 1999. Psychological safety and learning behavior in work teams. Administrative Science Quarterly, 44(2): 350-383.

Ely, R., \& Thomas, D. 2001. Cultural diversity at work: The effects of diversity perspectives on work group processes and outcomes. Administrative Science Quarterly, 46: 229-273.

Evered, R., \& Louis, M. R. 1981. Alternative perspectives in the organizational sciences: Inquiry from the "inside" and inquiry from the "outside." Academy of Management Review, 6: 365-395.

Forbes, D. P., \& Milliken, F. J. 1999. Cognition and corporate governance: Understanding boards of directors as strategic decision-making groups. Academy of Management Review, 24: 489-505.
Gibson, C., \& Vermeulen, F. 2003. A healthy divide: Subgroups as stimulus for team learning behavior. Administrative Science Quarterly, 48: 202-239.

Gillespie, A. 2011. Dialogical dynamics of trust and distrust in the Cuban Missile Crisis. In I. Marková \& A. Gillespie (Eds.), Trust and conflict: Representation, culture and dialogue. London: Routledge.

Gioia, D. A., \& Thomas, J. B. 1996. Identity, image and issue interpretation: Sensemaking during strategic change in academia. Administrative Science Quarterly, 41: 370-403.

Gioia, D. A., Thomas, J. B., Clark, S. M., \& Chittipeddi, K. 1994. Symbolism and strategic change in academia: Dynamics of sensemaking and influence. Organization Science, 5: 363-383.

Glaser, B. G., \& Strauss, A. 1967. The discovery of grounded theory. Chicago: Aldine.

Guetzkow, H. 1950. Unitizing and categorizing problems in coding qualitative data. Journal of Clinical Psychology, 6: 47-58.

Halevy, N., Chou, E. Y., \& D. Galinsky, A., 2011. A functional model of hierarchy: Why, how, and when vertical differentiation enhances group performance. Organizational Psychology Review, 1(1): 32-52.

Hambrick, D. C. 2007. Upper echelons theory: An update. Academy of Management Review, 32: 334-343.

Hambrick, D. C., \& D’Aveni, R. A. 1988. Large corporate failures as downward spirals. Administrative Science Quarterly, 33: 1-23.

Hambrick, D. C., \& D’Aveni, R. A. 1992. Top team deteriorates as part of the downward spiral of large corporate bankruptcies. Management Science, 38: 1445-1466.

Hambrick, D. C., \& Mason, P. A. 1984. Upper echelons: The organization as a reflection of its top managers. Academy of Management Review, 9: 193-206.

Hargadon, A. B., \& Douglas, Y. 2001. When innovations meet institutions: Edison and the design of the electric light. Administrative Science Quarterly, 46: 476-501.

Harrison, D. A., Price, K. H., \& Bell, M.P. 1998. Beyond relational demography: Time and the effects of surfaceand deep-level diversity on work group cohesion. Academy of Management Journal, 41(1): 96-107.

Harvey, S. 2013. A different perspective: The multiple effects of deep level diversity on group creativity. Journal of Experimental Social Psychology, 49: 822-832.

Harvey, S., \& Kou, C-Y. 2013. Collective engagement in creative tasks: The role of evaluation in the creative process in groups. Administrative Science Quarterly, 58: 346-386.

Hogg, M. A., \& Terry, D. I. 2000. Social identity and selfcategorization processes in organizational contexts. Academy of Management Review, 25: 121-140. 
Jackson, S. E., \& Joshi, A. 2004. Diversity in social context: A multi-attribute, multilevel analysis of team diversity and sales performance. Journal of Organizational Behavior, 25: 675-702.

Jick, T. D. 1979. Mixing qualitative and quantitative methods: Triangulation in action. Administrative Science Quarterly, 24: 602-611.

Kerr, S. 1975. On the folly of rewarding A while hoping for B. Academy of Management Journal, 18: 769-783.

Krippendorff, K. 1980 Content analysis: An introduction to its methodology. Beverly Hills, CA: Sage Publications.

Langley, A. 1999. Strategies for theorizing from process data. Academy of Management Review, 24: 691-710.

Lau, D. C., \& Murnighan, J. K. 1998. Demographic diversity and faultlines: The compositional dynamics of organizational groups. Academy of Management Review, 23: 325-340.

Lau, D. C., \& Murnighan, J. K. 2005. Interactions within groups and subgroups: The dynamic effects of demographic faultlines. Academy of Management Journal, 48: 645-659.

Levine, J. M., Choi, H-S., \& Moreland, R. L. 2003. Newcomer innovation in work teams. In P. B. Paulus \& B. A. Nijstad (Eds.). Group creativity: innovation through collaboration. New York: Oxford University Press.

Lewis, K., Belliveau, M., Herndon, B., \& Keller, J. 2007. Group cognition, membership change, and performance: Investigating the benefits and detriments of collective knowledge. Organizational Behavior and Human Decision Processes, 103: 159-178.

Lovelace, K., Shapiro, D. L., \& Weingart, L. R. 2001. Maximizing cross-functional new product teams' innovativeness and constraint adherence: A conflict communications perspective. Academy of Management Journal, 44(4): 779-793.

Loyd, D. L., Wang, C. S., Phillips, K. W., \& Lount, Jr., R. B. 2013. Social category diversity promotes premeeting elaboration: The role of relationship focus. Organization Science, 24: 757-772.

Li, J., \& Hambrick, D. C. 2005. Factional groups: A new vantage on demographic faultlines, conflict, and disintegration in work teams. Academy of Management Journal, 48: 794-813.

Lincoln, Y. S., \& Guba, E. G. 1985. Naturalistic inquiry. Beverly Hills, CA: Sage Publications.

Majchrzak, A., More, P., \& Faraj, S. 2012. Transcending knowledge differences in cross-functional teams. Organization Science, 23: 951-970.

Mannix, E., \& Neale, M. A. 2005. What differences make a difference? The promise and reality of diverse teams in organizations. Psychological Science in the Public Interest, 6(2), 31-55.
March, J. G. 1962. The business firm as a political coalition. The Journal of Politics, 24(4): 662-678.

Merton, R. K. 1957. Social theory and social structure. Glencoe, IL: Free Press.

Miles, M. B., \& Huberman, A. M. 1984. Qualitative data analysis: A source book of new methods. Beverly Hills, CA: Sage Publications.

Miller, G. A. 1956. The magical number seven, plus or minus two: Some limits on our capacity for processing information. Psychological Review, 63: 81-97.

Miller, T., \& Triana, M. 2009. Demographic diversity in the boardroom: Mediators of the board diversity-firm performance relationship. Journal of Management Studies, 46: 755-786.

Milliken, F. J., \& Martins, L. L. 1996. Searching for common threads: Understanding the multiple effects of diversity in organizational groups. Academy of Management Review, 21: 402-434.

Mohammed, S., \& Harrison, D. A. 2013. The clocks that time us are not the same: A theory of temporal diversity, task characteristics, and performance in teams. Organizational Behavior and Human Decision Processes, 122(2): 244-256.

Nemeth, C. J. 1986. Differential contributions of majority and minority influence. Psychological Review, 93(1): 23-32.

Nijstad, B. A., \& Kaps, S. C. 2008. Taking the easy way out: Preference diversity, decision strategies, and decision refusal in groups. Journal of Personality and Social Psychology, 94: 860-870.

Nunnally, J., \& Bernstein, I. 1994 Psychometric Theory (3rd ed.). New York: McGraw-Hill.

O’Reilly, C. A. 1980. Individuals and information overload in organizations: is more necessarily better? Academy of Management Journal, 23(4): 684-696.

Pelled, L. H., Eisenhardt, K. M., \& Xin, K. R. 1999. Exploring the black box: An analysis of work group diversity, conflict and performance. Administrative Science Quarterly, 44(1): 1-28.

Pentland, B. T. 1999. Building process theory with narrative: From description to explanation. Academy of Management Review, 24: 711-724.

Phillips, K. W., \& Loyd, D. L. 2006. When surface and deeplevel diversity collide: The effects on dissenting group members. Organizational Behavior and Human Decision Processes, 99: 143.

Phillips, K. W., Mannix, E. A., Neale, M. A., \& Gruenfeld, D. A. 2004. Diverse teams and information sharing: The effects of congruent ties. Journal of Experimental Social Psychology, 40: 497-510. 
Rink, F., \& Ellemers, N. 2006. What can you expect The influence of gender diversity in dyads on work goal expectancies and subsequent work commitment. Group Processes and Intergroup Relations, 9: 577-588.

Rink, F. A., \& Ellemers, N. 2009. Temporary versus permanent group membership: How the future prospects of newcomers affect newcomer acceptance and newcomer influence. Personality and Social Psychology Bulletin, 35: 764-775.

Scott, W. A. 1955. Reliability of content analysis: The case of nominal scale coding. Public Opinion Quarterly: 321-325.

Simon, H. A. 1957. Administrative Behavior: A Study of decision-making processes in administrative organizations. New York: Free Press.

Simons, T., Pelled, L. H., \& Smith, K. A. 1999. Making use of difference: Diversity, debate, and decision comprehensiveness in top management teams. Academy of Management Journal, 42: 662-673.

Spradley, J. 1980. Participant Observation. New York: Holt, Rinehart and Winston.

Srikanth, K., Harvey, S., \& Peterson, R. S. 2016. A dynamic perspective on diverse teams: Moving from the dualprocess model to a coordination-based model of diverse team performance. Academy of Management Annals, 10: 453-493.

Suddaby, R. 2006. From the editors: What grounded theory is not. Academy of Management Journal, 49: 633-642.

Tajfel, H., \& Turner, C. 1979. An integrative theory of intergroup conflict. In W. Austin \& S. Worchel (Eds.). The social psychology of intergroup relations, chapter 3: 33-47. Monterey, CA: Brooks/Cole.

Thatcher, S. M. B., Jehn, K. A., \& Zanutto, E. 2003. Cracks in diversity research: The effects of diversity faultlines on conflict and performance. Group Decision and Negotiation 12: 217-241.

Tuggle, C. S., Schnatterly, K., \& Johnson, R. A. 2010. Attention patterns in the boardroom: How board composition and processes affect discussion of entrepreneurial issues. Academy of Management Journal, 53: 550-571.

van der Vegt, G. S., \& Bunderson, S. 2005. Learning and performance in multi-disciplinary teams: The importance of collective team identification. Academy of Management Journal, 48: 532-547.

van der Vegt, G. S., Bunderson, S., \& Kuipers, B. 2010. Why turnover matters in self-managing work teams: Learning, social integration, and task flexibility. Journal of Management 36: 1168-1191.

van der Walt, N. T., \& Ingley, C. B. 2003. Board dynamics and the influence of professional background, gender, and ethnic diversity of directors. Corporate Governance: An International Review, 11: 218-234. van Knippenberg, D., De Dreu, C. K. W., \& Homan, A. C. 2004. Work group diversity and group performance: an integrative model and research agenda. Journal of Applied Psychology, 89: 1008-1022.

van Knippenberg, D., \& Schippers, M. C. 2007. Work group diversity. Annual Review of Psychology, 58: 515-541.

Van Maanen, J. 1979. The fact of fiction in organizational ethnography. Administrative Science Quarterly, 24: 539-550.

Warner, W. K., \& Havens, A. E. 1968. Goal displacement and the intangibility of organizational goals. Administrative Science Quarterly, 12: 539-555.

Weick, K. E. 1993. The collapse of sensemaking in organizations: The Mann Gulch disaster. Administrative Science Quarterly, 38: 628-652.

Whyte, W. F. 1943. Street corner society. Chicago: University of Chicago Press.

Whyte, W. F. 1979. On making the most of participant observation. The American Sociologist, 14: 56-66.

Williams, K., \& O’Reilly, C. 1998. Demography and diversity in organizations: A review of 40 years of research. In B. M. Staw \& L. L. Cummings (Eds.). Research in organizational behavior, vol. 20: 77-140. Greenwich, CT: JAI Press.

Yin, R. K. 2003. Case study research: Design and methods (3rd ed.). Thousand Oaks, CA: Sage Publications.

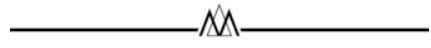

Sarah Harvey (sarah.r.harvey@ucl.ac.uk) is an Associate Professor of Organizational Behavior at the UCL School of Management. Her research examines dynamic group processes, focusing particularly on creativity and diversity in groups and teams. Her work has been published in journals such as Administrative Science Quarterly and Academy of Management Review.

Steven C. Currall (scc@smu.edu) is Provost and Vice President of Academic Affairs at Southern Methodist University. He holds professorial appointments in the Cox School of Business, Dedman College of Humanities and Sciences, and Lyle School of Engineering. He served on the editorial boards of the Academy of Management Review, Academy of Management Journal, and Academy of Management Perspectives.

Tove Helland Hammer (thh2@cornell.edu) is Professor and Chair of Organizational Behavior at the ILR School, Cornell University. She served as the editor of the ILRREVIEW, associate editor of the Journal of Occupational and Organizational Psychology, and on the editorial boards of Administrative Science Quarterly, Journal of Applied Psychology, Journal Vocational Behavior, and Groups and Organization Studies. 
APPENDIX A

Content Analysis

Verbal Behavior Categories

Examples

Task-focused Comments Information giving

Information seeking

Making specific suggestions for action

Sensible, nonpersonal arguments

Corporate interests

Sub-group Interest-based Comments Special interest group gains and positions

Attempts to propose new board topics

Affective Conflict Comments

Personal defensiveness

Personal gains

Disagreements, conflicts, attacks

Stonewalling

Decisions

Motion making

Motion seconding

\section{Other}

Making statements in support of another person's argument

Agreeing reluctantly

Tension management

Direction of traffic

Collective spirit and solidarity moves
"The new kill-line is up and we are now at 60 hogs an hour."

"When is the final stock purchase?"

"I want a letter from RP (company lawyer) which says that Mr. X will have to pay up or they'll be pulled into court."

"To get out of the dependence on the cut-out, we have to use all possible parts of the hog and turn everything we can into processed meat"

"We (the company and the union) should go down to the IRS and argue this out-they should not stop us now."

In a discussion about a union concession, an employee director says, "Don't roll back the pension. Don't tamper with the pension, because that'll undo morale."

In the middle of a discussion about wildcat strikes, a director gets annoyed and says, "I want us to get to the issue of compensation and can we cut out all this rhetoric?"

CEO (whining) "Everything we do here is being held up by the PBGC not signing."

Director of sales and marketing (a board member) recounting how all the competitors are underselling and losing money says, "But we [sales and marketing] have gotten two new large orders [he describes them], which is a breakthrough for the company."

In a discussion about poor first-line supervision, the personnel director explains that some line supervisors were hired off the Coca-Cola bottling plant, and a director turns on him and says, "How on earth could we hire someone from Coca-Cola and not train him?"

Director to the CEO: "When will you start to negotiate?" (Referring to a master union agreement, a controversial issue.) CEO does not respond and instead asks the employee directors a question.

One director: "For heaven's sake, don't give him a title; he has to do it his way." Chairman: "I agree."

Following a discussion about whether some product cost reductions have been passed on to sales, the CEO finally admits that it has been passed on to the salesman, although he said "No it hasn't" initially.

"...LT and HE are doing a good job, and we should encourage that and ask them to keep going."

The CEO asks the board chairman to move to agenda item \#10: health insurance.

CEO, addressing the local union officers, those who are present on the board, and the board itself: "We're all in the same boat now; we'll have to pull together." 